\begin{abstract}
S
Elmar Brok and Martin Selmayr

The 'Treaty of Parliaments' as a Danger to Democracy? On the Evidently Unfounded Complaints of Unconstitutionality Against the Lisbon Treaty

The reform of the EU is hanging on by a thread since the Irish 'No' to the Lisbon Treaty in June 2008. Of all countries, Germany has now emerged as a country in which ratification could be endangered or at least delayed. The reason for this are two constitutional challenges against the German ratification law to the Lisbon Treaty, which are currently pending at the Federal Constitutional Court. The authors show that the new Treaty is in no way a danger to democracy, as suggested by the constitutional court challenges. Instead, because of the numerous parliamentfriendly aspects, it rather deserved to be called 'Treaty of the Parliaments'. The authors explain the many ways in which the Lisbon Treaty is strengthening democracy and parliamentarianism in the EU, thereby paving the way towards a more democratic and participatory Union. Against this background, the constitutional challenges against the Lisbon Treaty are - insofar as they are admissible at all - in any case, evidently unfounded.
\end{abstract}

\title{
Hans Stark
}

The French EU Presidency 2008 - Between Crisis Management and Strategic Planning

France started off its EU Presidency under highly difficult circumstances. For one thing, Paris has set high, maybe too high goals. For another thing, the 'No'-vote of the Irish from the 12th of June 2008 created considerable confusion regarding the further course of the ratification process and the entering into force of the Lisbon Treaty. Initially, both should have been clarified during the French EU Presidency. France has, therefore, to master an EU crisis that resembles the one which the French 'No'-vote of 2005 had provoked. Simultaneously, a lot of decisions have to be prepared in the second half of 2008 that are to be taken in 2009.

Jo Leinen and Jan Kreutz

The Challenge of Participatory Democracy: Civil Society and Direct Democracy in the Lisbon Treaty

The result of the Irish referendum showed again the need for a more democratic and more participatory EU. This presupposes that civil society is involved in agenda-setting, in shaping European policies, their implementation and dissemination. An interinstitutional agreement should be considered that includes guidelines for the dialogue with civil society. It is also necessary that the work of Council and Commission becomes more transparent and that citizens have direct access to EU documents. A great leap forward to participatory democracy will be the petition of European citizens. European citizens will thus be able to influence the political agenda of the EU and take the initiative of inviting the Commission to submit a proposal. In future, the introduction of a European referendum is also imaginable. Yet, this would only further European integration and democratisation of the EU if it will be more than the sum of 27 national referenda.

Sven Hölscheidt

\section{Formal Upgrading - Low Driving Potential: the Role of National Parliaments According to the Lisbon Treaty}

The Lisbon Treaty assigns a larger role to national parliaments than the current Nice Treaty. The national parliaments owe this to the European Convention. Yet, will this formally strengthened 
role of national parliaments also have an impact on political practices if the Treaty of Lisbon enters into force? The author outlines the tasks of national parliaments and their possibilities of participation in the EU. He comes to the conclusion that the 'tendency towards de-parliamentarisation of the EU' continues.

\section{Elfriede Regelsberger}

\section{From Nice to Lisbon - the New Constitutional Offer for the Common Foreign and Security Policy of the EU}

Compared to the existing provisions of the Nice Treaty, the Lisbon Treaty offers a remarkable potential to improve the EU's role as a global actor in foreign and security policy. Readers might have pains to find their way through a much more complex and partly repetitive contractual basis but the new text opens ways to improve the visibility, continuity and effectiveness of the Common Foreign and Security Policy (CFSP). The end of the rotating presidency and its replacement by a more permanent and double-hatted 'face and figure' in the form of the High Representative of the Union for Foreign Affairs and Security Policy, accompanied by an European External Action Service is key hereof. Permanent Structured Cooperation in the area of the somewhat re-named 'Common' Security and Defence Policy (CSDP, currently ESDP) will turn out as another important tool to improve ESDP-capabilities of those among the 27 who wish to advance quicker than the others. The Irish 'No' will not only prolong the ratification procedure but might also have negative effects for the solution of a number of institutional details the reform debate has been unable to tackle sufficiently so far.

\section{Matthias Oel and Juliane Rapp-Lücke}

\section{Preparing Political Decision Making in the EU-27 plus: the Example of European Home Affairs}

Within less than three years, the number of EU member states has almost doubled from 15 to 27. New methods of forming political opinions and preparing decision making must be attempted between the European Commission, the member states and the European Parliament, especially with regard to possible further enlargements. Taking European Home Affairs as an example, the authors outline the current processes of political opinion formation inside and outside of the Council. They present, as a possible model for modern preparation of decision making in the EU-27 plus, the 'High-Level Advisory Group on the Future of European Home Affairs Policy', established during the German EU Presidency in the first half of 2007, and its work.

\section{Dieter Plehwe}

\section{Transformation of European Governance in the Field of Transport Policy}

Studies of European integration rely increasingly on quantitative methods. Quantitative analyses of European law have been used to show that some hypotheses about an excessive transformation of European governance (cooperation instead of hierarchy) are to be rejected, but also to support problematic hypotheses about the Europeanization of policy fields. The development of quantitative methods is just at the beginning and has to cope with serious problems, for example with the data concerning the official EUR-Lex-classification or the various legal instruments of the EU. A systematic analysis of policy fields and the differentiation between different types of legal instruments offer a possibility to improve quantitative analyses and integrate the so far separately analysed perspectives of Europeanization and governance. In this article, the development of European transportation law is examined in order to exemplify the quantitative development of 
European law. The author shows how a quantitative analysis of European law may be used to originate hypotheses regarding the heterogeneous transformation of European governance.

\section{Jo Leinen and Jan Kreutz}

\section{The Irish 'No' to the Lisbon Treaty: Options for Solving this New Crisis}

The Irish 'No' poses a great problem for the EU. On the one hand, the result cannot be ignored, on the other hand, the cooperation of 27 member states and 500 million people cannot be blocked by 862.415 people from one member state. It remains true that the EU is - with the Nice Treaty - not capable of solving the challenges of the 21 st century efficiently and effectively. A lot speaks for a second referendum with certain promises and guaranties for Ireland. The debate has to be based, though, on a better understanding of the reasons for the Irish 'No'. To draw consequences of the 'No', measures in communication policy have to be taken and decisions of the EU have to be better suited to the wishes of the people. Furthermore, with regard to the ratification process so far, the ratification method for treaty changes itself has to be questioned.

\section{Wolfgang Wessels}

\section{The Debate After 'Ireland': Insisting on Lisbon, Looking for New Alternatives, or Living with Nice?}

The controversial and emotional debate on the Irish referendum on the Lisbon Treaty shows a number of different evaluations and strategies. These do not only provide different suggestions, but also a lot of different analyses of the status quo and the developments of the EU. It thus seems reasonable to integrate the variety of opinions in the following schools of thought: Insisting on the Lisbon Treaty, deepening integration in a core Europe, founding a new Europe, and living with the Nice Treaty. The author analyses and evaluates these schools of thought with regard to their explicit and implicit assumptions, expectations and implications. In view of the many sceptical voices, this article advocates a careful consideration that, in the case of a failure of the Lisbon Treaty, a productive - even if compared to the Lisbon Treaty more arduous - life with the Nice Treaty is possible and perhaps necessary.

\section{Heinrich Schneider}

\section{'Keep Going!' - or Something Totally New? European Politics After the Irish 'No'}

Media and European politicians are worried about the crisis precipitated by the Irish 'No'. But the current crisis is not only made up of the Irish 'No': the Lisbon Treaty does only overcome some of the unresolved problems of the EU. Particularly the succession of insufficient (Nice Treaty) or failed reforms (Constitutional Treaty, Lisbon Treaty) gives reason to consider whether the current strategy is a promising one. Many proposals, though, seem to aim only at dealing with the immediate crisis or at improving the image of the EU. Is this really enough? At least critical observers in academia and media should attempt to come up with new ideas. Without developing new perspectives, the EU will not be able to really find a way out of the current crisis.

Übersetzungen aus dem Deutschen von Jaren Kuchta und Tanja Leppik-Bork. 